\title{
A Comparison between the Grain Quality Parameters of Rice Grown under Organic and Inorganic Production System
}

\author{
Hem. C. Joshi ${ }^{1, *}$, Om Prakash ${ }^{2}$, M. K. Nautiyal ${ }^{3}$, B. S. Mahapatra ${ }^{4}$, S. K. Guru ${ }^{1}$ \\ ${ }^{1}$ Department of Plant Physiology, College of Basic Sciences and Humanities, G.B.P.U.A. \&T. Pantnagar, India \\ ${ }^{2}$ Department of Chemistry, College of Basic Sciences and Humanities, G.B.P.U.A. \&T. Pantnagar, India \\ ${ }^{3}$ Department of Genetics \& Plant Breeding, College of agriculture, G.B.P.U.A \&T. Pantnagar, India \\ ${ }^{4}$ Department of Agronomy, College of agriculture, G.B.P.U.A \& T. Pantnagar, India
}

Copyright $\subseteq 2019$ by authors, all rights reserved. Authors agree that this article remains permanently open access under the terms of the Creative Commons Attribution License 4.0 International License

\begin{abstract}
India contributes about one-third of the world acreage under rice. Rice is available in over 5000 varieties, of which Basmati rice occupies a prime position on account of its extra long superfine slender grains, pleasant, exquisite aroma, fine cooking quality, sweet taste, soft texture, length-wise elongation with least breadth-wise swelling on cooking and tenderness of cooked rice. The present work was undertaken to compare the effect of an organic and inorganic method of cultivation on the quality of rice. The results revealed higher hardness, true density and percent porosity in inorganic grains of rice. Inorganic rice had better milling quality but cooking quality was found better of organic rice as evident from higher elongation ratio and swelling rate. Organically grown foods were found to be tastier in comparison to inorganic foods as organic samples scored higher for all the parameters of sensory. Moisture content was found higher in inorganic rice. The quantity of protein was less, but the quality was better in organic crops as measured by in-vitro protein digestibility. No definite trend was seen for effect of inorganic and organic mode of cultivation on total ash, crude fiber and carbohydrate content on rice crops. Iron was found to be significantly higher in organic rice (1.32 $\mathrm{mg} / 100 \mathrm{~g}$ ); phosphorus was significantly higher in inorganic rice $(112.80 \mathrm{mg} / 100 \mathrm{~g})$. No significant difference was observed in manganese, cobalt, zink and copper content of the produced from an organic and inorganic mode of cultivation.
\end{abstract}

Keywords Organic, Inorganic, Rice, Food Quality

\section{Introduction}

Rice (Oryza sativa) the staple food of nearly one-half of world's population, contributes over $20 \%$ of the total calorie intake of man. But in Asia, where $95 \%$ of the world's rice is produced and consumed, it contributes $40 \pm 80 \%$ of the calories of the Asian diet. India is one of the largest rice growing countries of the world, second only to China, cultivating 43 million hectares annually, which is about a third of the world acreage under rice [1]. Oryza sativa is the major cereal crop of India, being available in over 5000 varieties differing with respect to size, texture, glutinous nature, aroma and cooking quality [2]. Indian agriculture is facing the strenuous task to provide food security as well as nutritional security for all. According to UNDP, safeguarding national food security means improving the quality of life of the farming community by ensuring no further depletion of the natural resource base. The most desirable way to meet the food grain requirements is the maintenance of good soil health and stability in production through the use of organic and biological resources. Organic agriculture is one of the most widely practiced, diversified conventional farming systems to make agriculture sustainable.

Increasing consumer awareness of health and social equity issues, as well as the environmental problems associated with industrial-scale agriculture, has resulted in widespread interest in organic food production systems. The demand for organic food is steadily increasing both in the developed and developing countries with an annual average growth rate of 20-25 percent [3]. Organic agriculture, without doubt, is one of the fastest-growing sectors of agricultural production. However, before embarking on a large conversion to organic agriculture, it should be judged over inorganic farming in terms of production, the effect on the environment, cost of production and quality. Keeping this in view, the present investigation was undertaken with a view to compare the effect of organic and inorganic source of nutrients on the 
quality of rice.

\section{Materials and Methods}

Samples of organically as well as inorganically produced rice (Pant Basmati 1) were obtained from obtained from the Organic agriculture technology block, G.B. Pant University of Agriculture and Technology, Pantnagar. After harvesting, rice was cleaned to remove dust, grit and other impurities. Paddy was milled in a laboratory mill (Department of Post Harvest Process \& Food Engineering, College of Technology). For the analysis of Physical characteristics and cooking characteristics, whole grains were used. Whole grains of rice (both organic as well as inorganic) were kept in airtight containers. The samples of rice was analyzed for grain quality and different parameters assessed under grain quality were thousand kernel weight, hardness, hydration capacity, bulk density, true density, per cent porosity and seed volume.

The thousand kernel weight of grains was determined as the hundred kernels of each sample were counted manually and weighed in an electronic balance with 0.001 least count. The weight was multiplied by 10 and expressed as thousand kernel weight. Six replicates each of three average sized grains were taken to determine the kernel hardness, using the Grain hardness tester. Force required to break a grain was measured and expressed as hardness in kilogram per grain. Hydration capacity of rice grains was calculated by putting 100 seeds of known weight in a 150 $\mathrm{ml}$. conical flask and $100 \mathrm{ml}$ water added to it. The flask was stopped and left overnight. Next day the water was drained off and seeds were air dried and weighed. The hydration capacity was recorded by substracting weight before soaking from the weight after soaking. Seed volume was calculated by putting hundred seeds into a graduated jar containing water. Volume displaced by it was measured in $\mathrm{ml}$.

Bulk density of samples was done by weighing the quantity of rice filled in an aluminum container. The volume occupied by the grains is determined by measuring the volume of water required to fill the container to the brim. Bulk density was expressed as $\mathrm{g} / \mathrm{ml}$. The true density of grains was determined by modification of kerosene oil displacement procedure in which Ten gram sample was carefully immersed in $50 \mathrm{ml}$ of toluene in a measuring cylinder and increase in volume of solvent was noted. The increase in volume represents the actual volume occupied by the grains. The Per cent porosity of grains was calculated using following formula:

$$
\text { Per cent porosity }=\frac{\text { True density }- \text { Bulk density }}{\text { True density }} \times 100
$$

The length and breadth of ten rice kernels were measured by a vernier caliper and recorded in millimeters. The average length and breadth was then calculated. The average length gave the size whereas the length/breadth ratio gave shape of the kernel. The six polished whole kernels of each sample were placed evenly in petridishes of $9 \mathrm{~cm}$ diameter containing $10 \mathrm{ml}$ of 1.4 per cent potassium hydroxide solution. The petridishes were covered and left undisturbed at room temperature for 23 hours. The samples were then rated photographically for the degradation of kernels on a scale of 1 to 7. The average score of the 6 kernels was taken as the alkali score of the sample $[4,5]$.

The milling quality of rice was assessed in terms of hulling yield, milling yield and degree of polishing. In Cooking quality analysis the sample of organically and inorganically produced grains of rice was subjected to open pan cooking and pressure cooking for different timings and per cent cooking was observed in each case. All the estimations were done in triplicate. The cooking quality of rice was assessed in terms of elongation ratio and swelling rate.

For sensory quality analysis we were used the triangle test. Before the test organic and inorganic samples rice was cooked and the sensory evaluation was done using sensory scorecard with parameters viz. color, taste, flavor, texture, appearance and overall acceptability.

Nutrient composition of both organic and inorganic samples of rice was done by estimating proximate composition, in-vitro protein digestibility, and minerals. Proximate composition is the term applied to the proportion of water, fat, protein, carbohydrate, ash and fibre present in food. For the moisture content, the two gram of sample was weighed and oven dried in a pre-dried and pre-weighed aluminum dish for 3 hours at $105^{\circ} \mathrm{C}$. The loss in weight of the sample after drying was taken as moisture content and reported as percentage. For the estimation of crude fat, Five gram of sample was extracted for 16 hours in soxhlet apparatus using petroleum ether as solvent with a boiling range of $40-60^{\circ} \mathrm{C}$. The extracted fat was collected in a pre-weighed loss beaker. The petroleum ether was removed by evaporation. Difference in weight of the beaker represented crude fat content and was reported as per cent crude fat/ether extract [6]. In-vitro protein digestibility was determined following the procedure of Akeson and Stahman (1964) for digestion of protein and determining protein by Degroot and Stump method (1961). Iron was estimated by Wong's method [7], phosphorus by Fiske and Subba Row method, Manganese, cobalt, and copper were estimated using atomic absorption spectrophotometer.

\section{Results and Discussion}

Different parameters which are the indicators of rice grain quality were recorded during both the seasons to assess the effect of nutrient sources on these parameters. The data is presented in Fig. 1 to 12 (Table 1 to 5 in Appendix). Among the quality parameters, thousand 
Kernel Weight, Bulk Density, Hydration Capacity, Seed Volume, Length/Breadth Ratio, Alkali Score, Degree of Polishing (\%),Available Carbohydrate (\%),Total Ash (\%),Crude Fibre (\%), Zinc were unaffected by source of nutrients. However significant effects of source of nutrients were observed in the parameters Kernel Hardness, True Density, Per Cent Porosity, Hulling Yield
(\%), Milling Yield (\%), Moisture (\%), Crude Protein (\%), Crude Fat (\%) and Iron element. The true density and iron element was significantly higher in organic system of nutrient however the Per cent porosity, Hulling yield (\%), Milling yield (\%),Moisture (\%),Crude Protein (\%) and Crude Fat (\%)was significantly higher in inorganic system of nutrient.

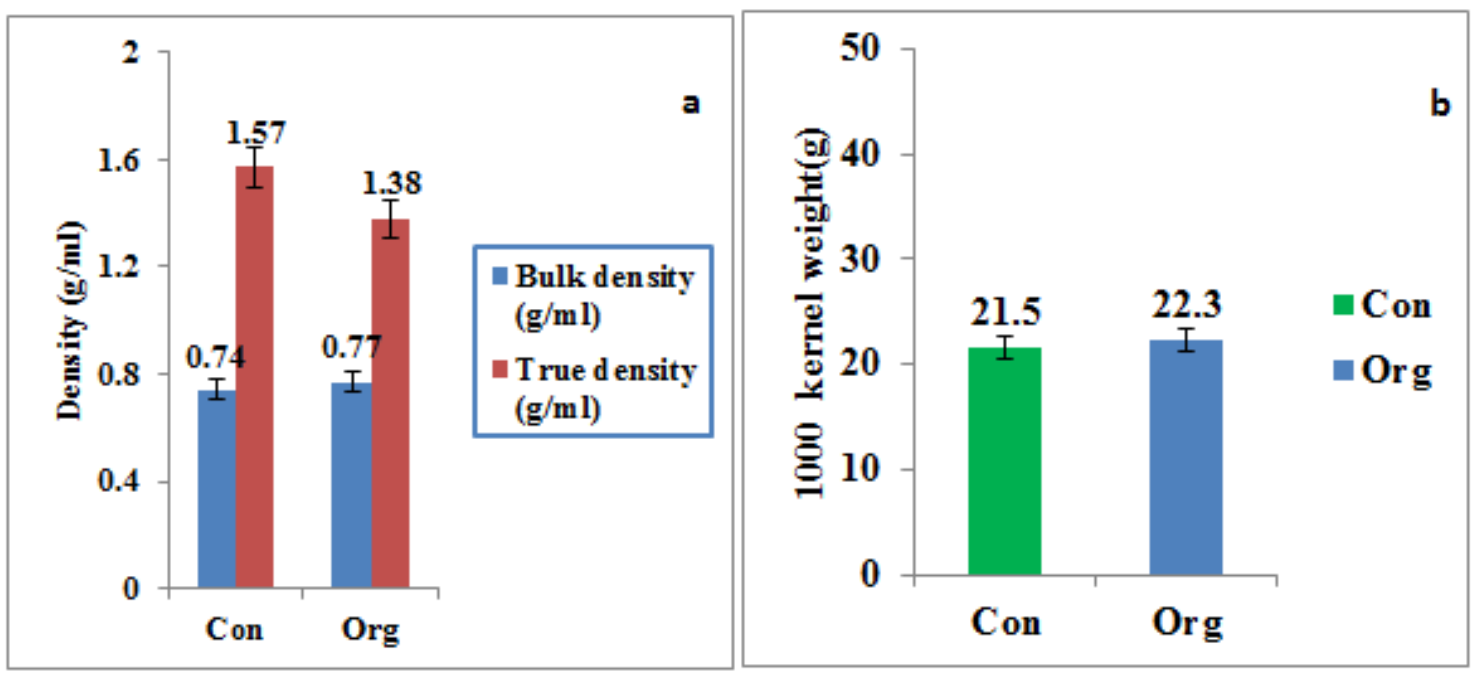

Figure 1. a\&b Effect of inorganic and organic sources of nutrients on Bulk density $(\mathrm{g} / \mathrm{ml})$, True density $(\mathrm{g} / \mathrm{ml})$ and 1000 kernel weight ( $\mathrm{g}$ ) in rice variety Pant Basmati 1
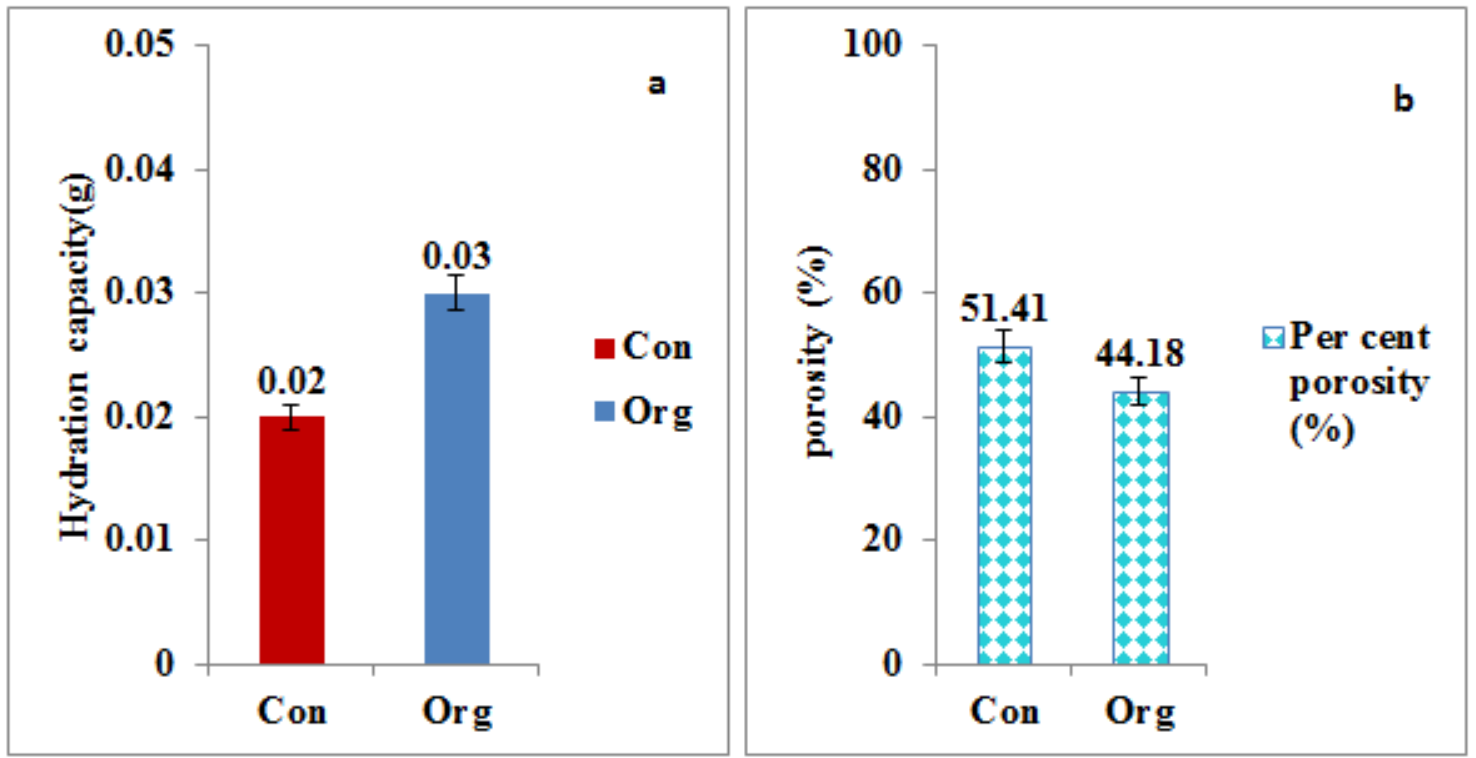

Figure 2. a \& b. Effect of organic and inorganic nutrient sources on Hydration capacity and porosity (\%) in rice variety Pant Basmati 1 


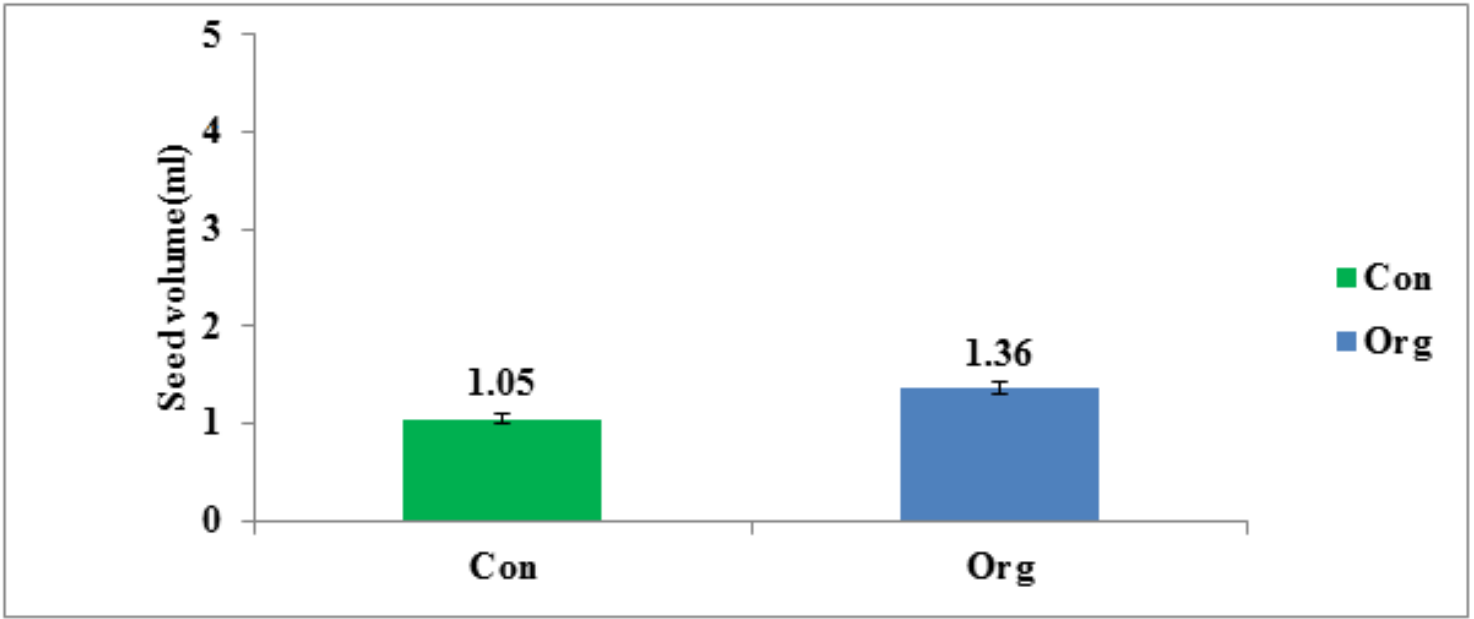

Figure 3. Effect of organic and inorganic nutrient sources on Seed volume (ml) in rice variety Pant Basmati 1

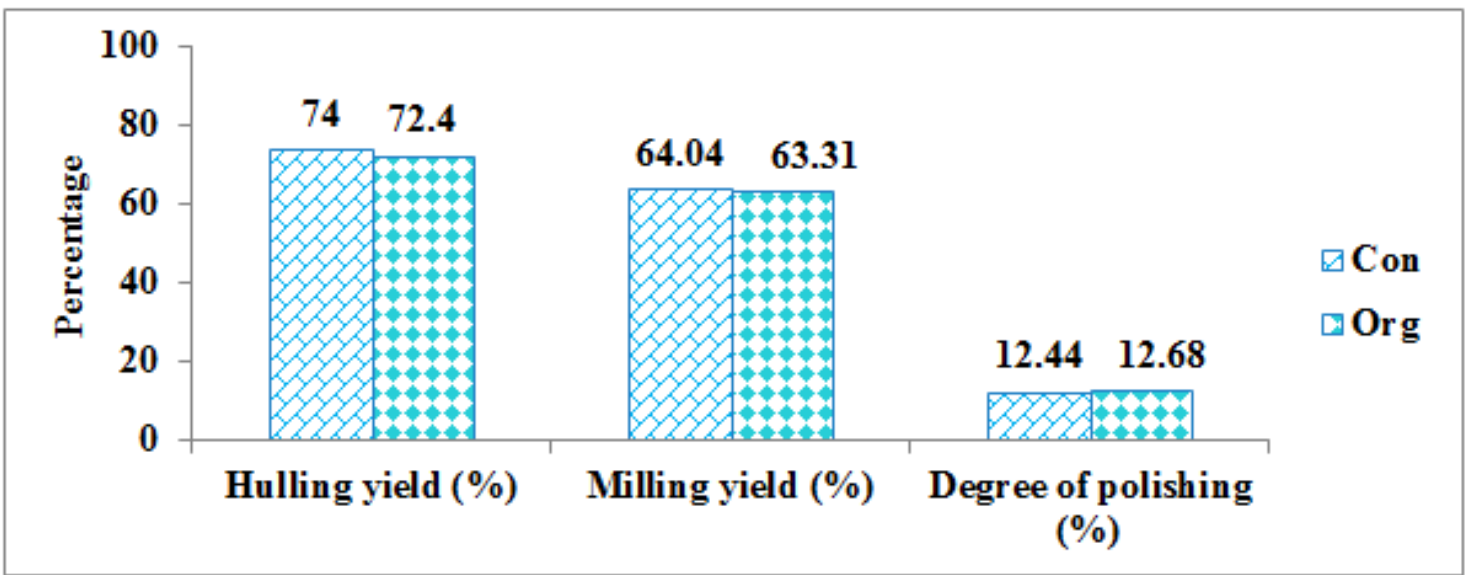

Figure 4. Effect of different nutrients on Hulling yield (\%), Milling yield (\%) \& Degree of Polishing (\%) in rice variety Pant Basmati 1
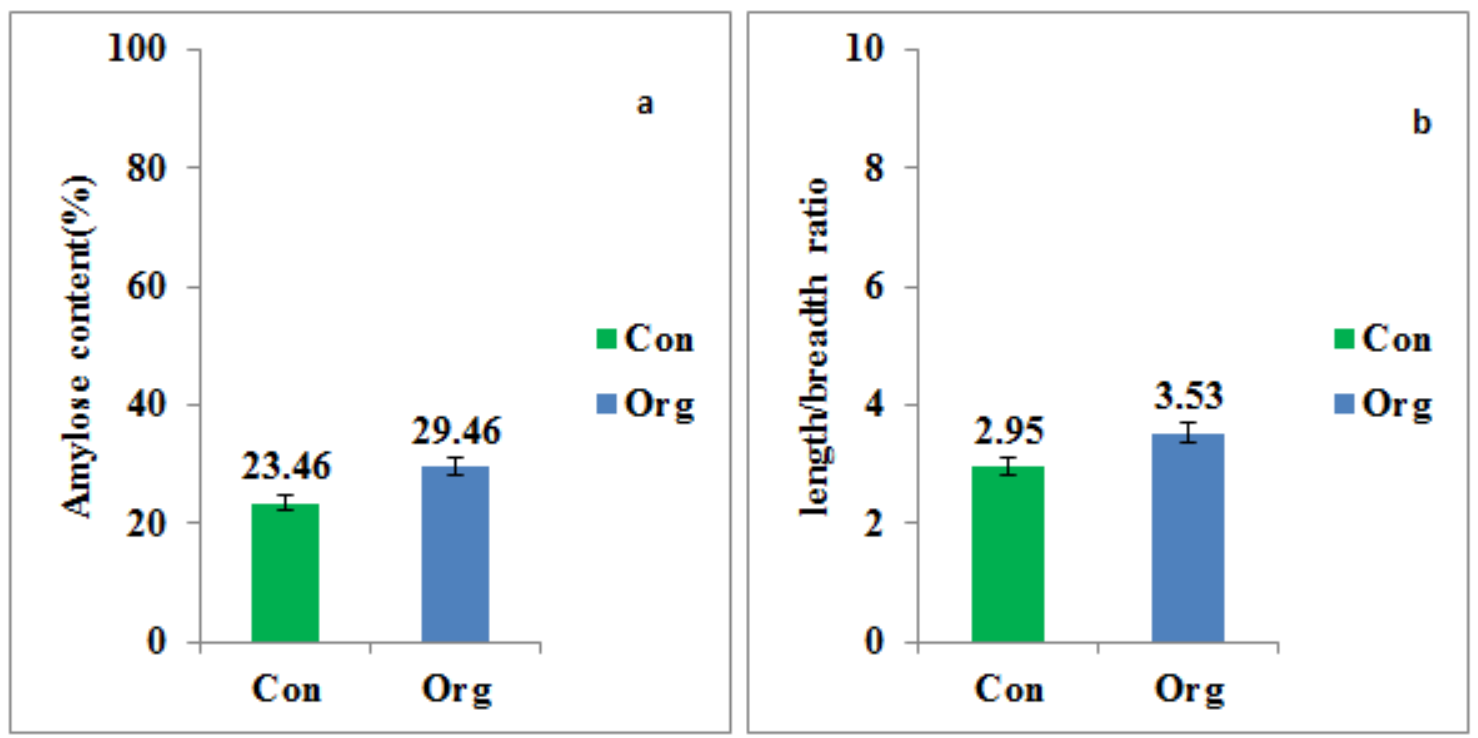

Figure 5. a \& b: Effect of organic and inorganic nutrient sources on Amylose Content and length/breadth ratio in rice variety Pant Basmati 1 


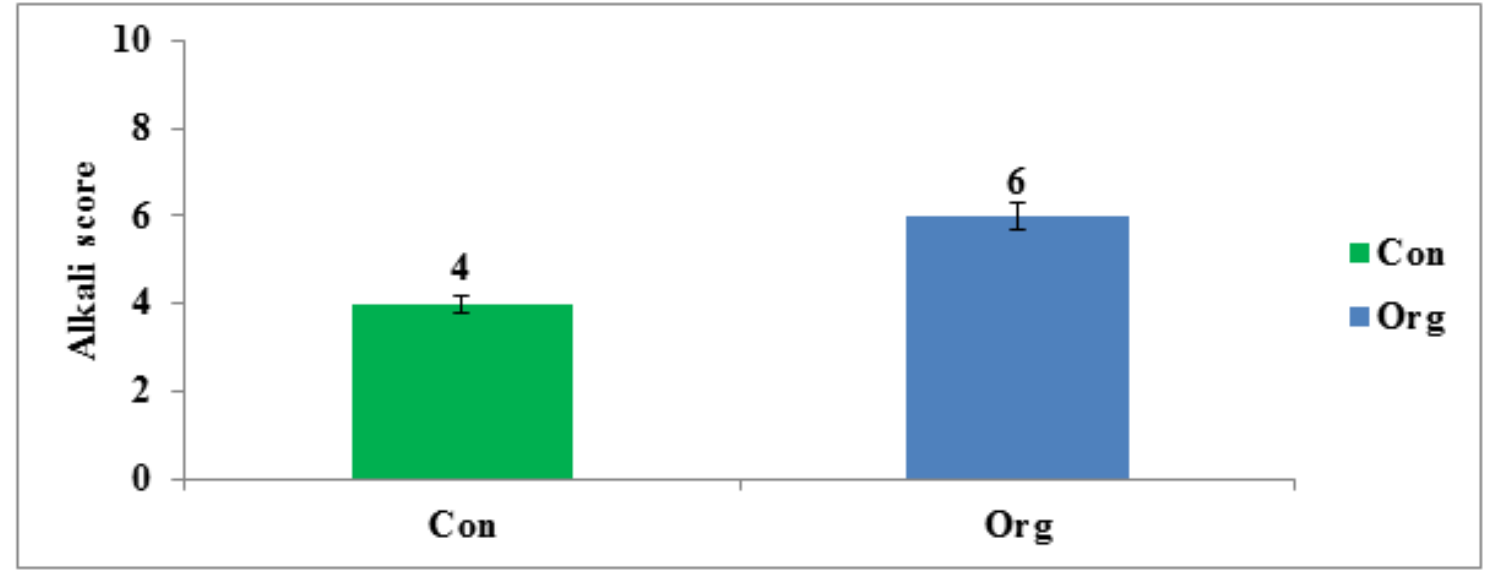

Figure 6. Effect of organic and inorganic nutrient sources on Alkali score of rice variety Pant Basmati 1

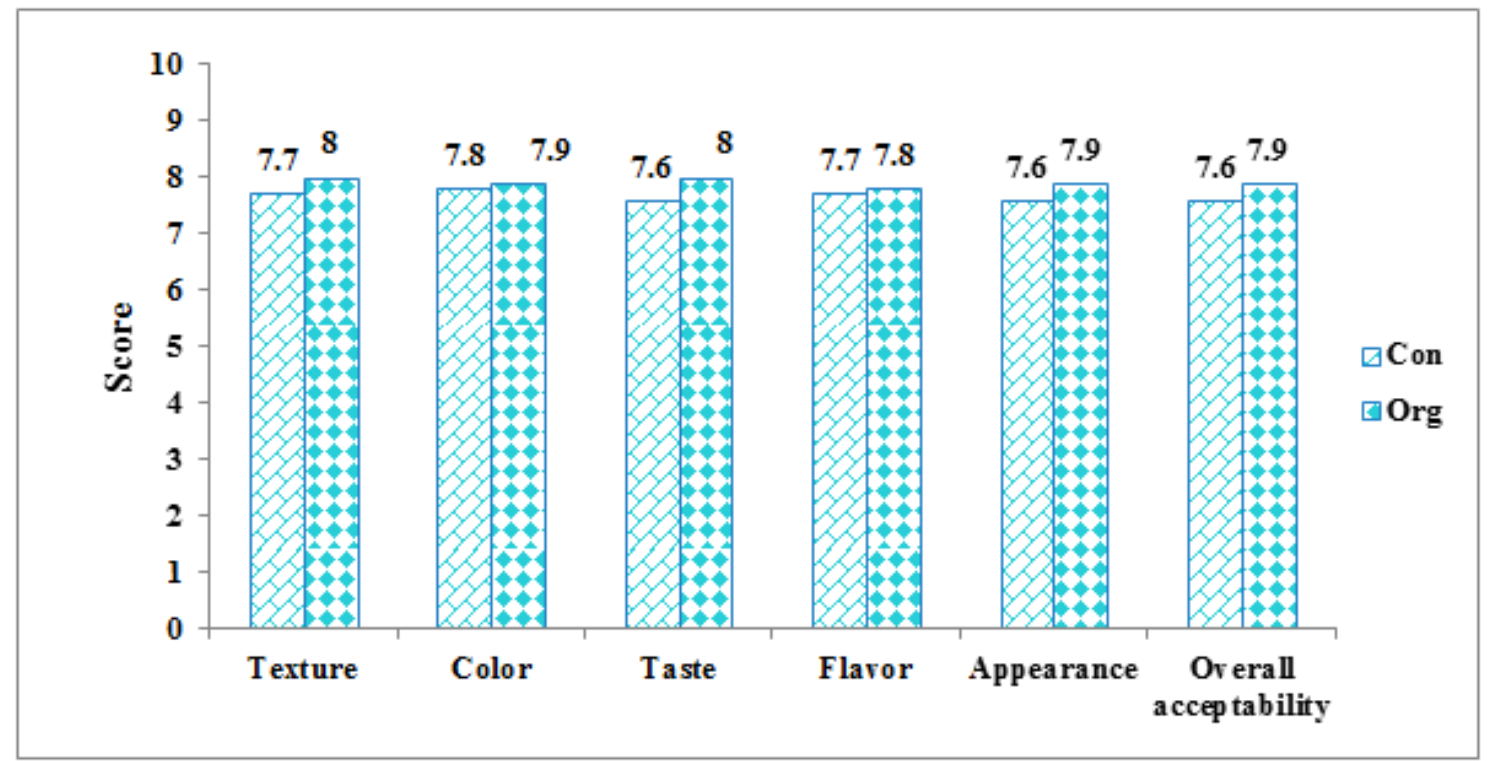

Figure7. Effect of organic and inorganic nutrient sources on Sensory Quality in rice variety Pant Basmati 1

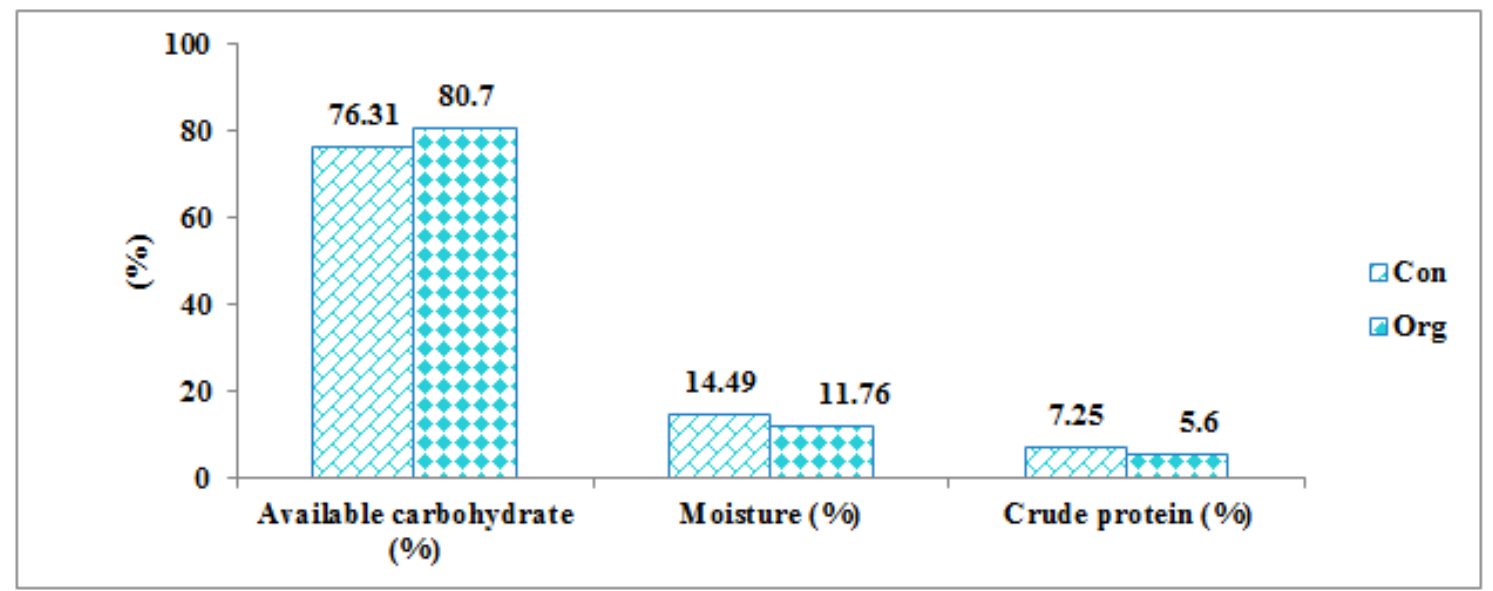

Figure 8. Effect of different nutrients on Available Carbohydrate (\%), Moisture (\%) \& Crude Protein in rice variety Pant Basmati 1 


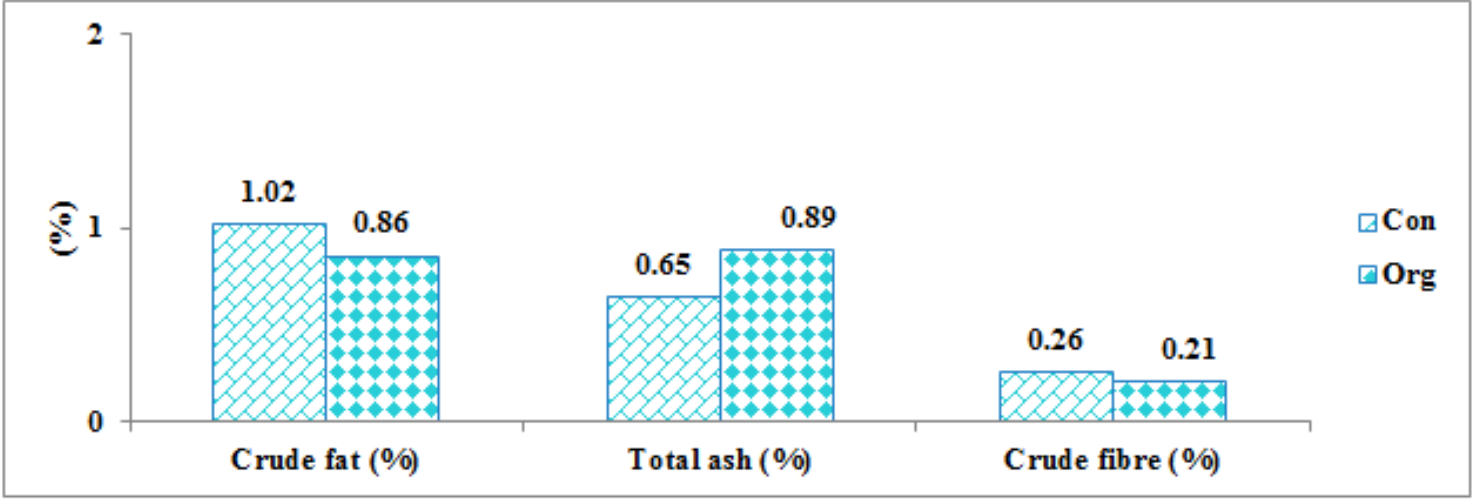

Figure 9. Effect of different nutrients on Crude fat (\%), Total ash (\%) \& Crude Fiber (\%) in rice variety Pant Basmati 1

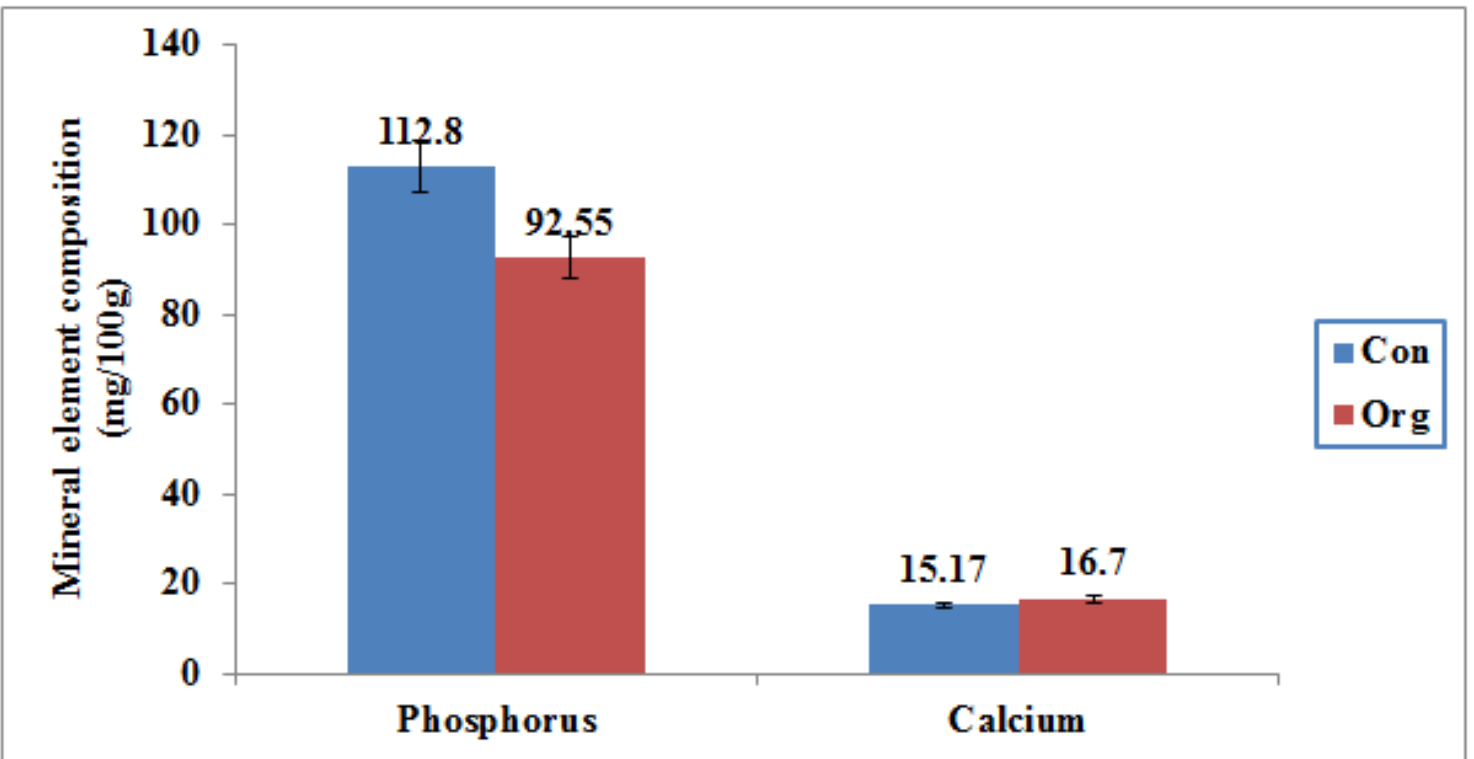

Figure 10. Effect of organic and inorganic nutrient sources on Mineral and trace element composition $(\mathrm{mg} / 100 \mathrm{~g})$ in rice variety Pant Basmati 1

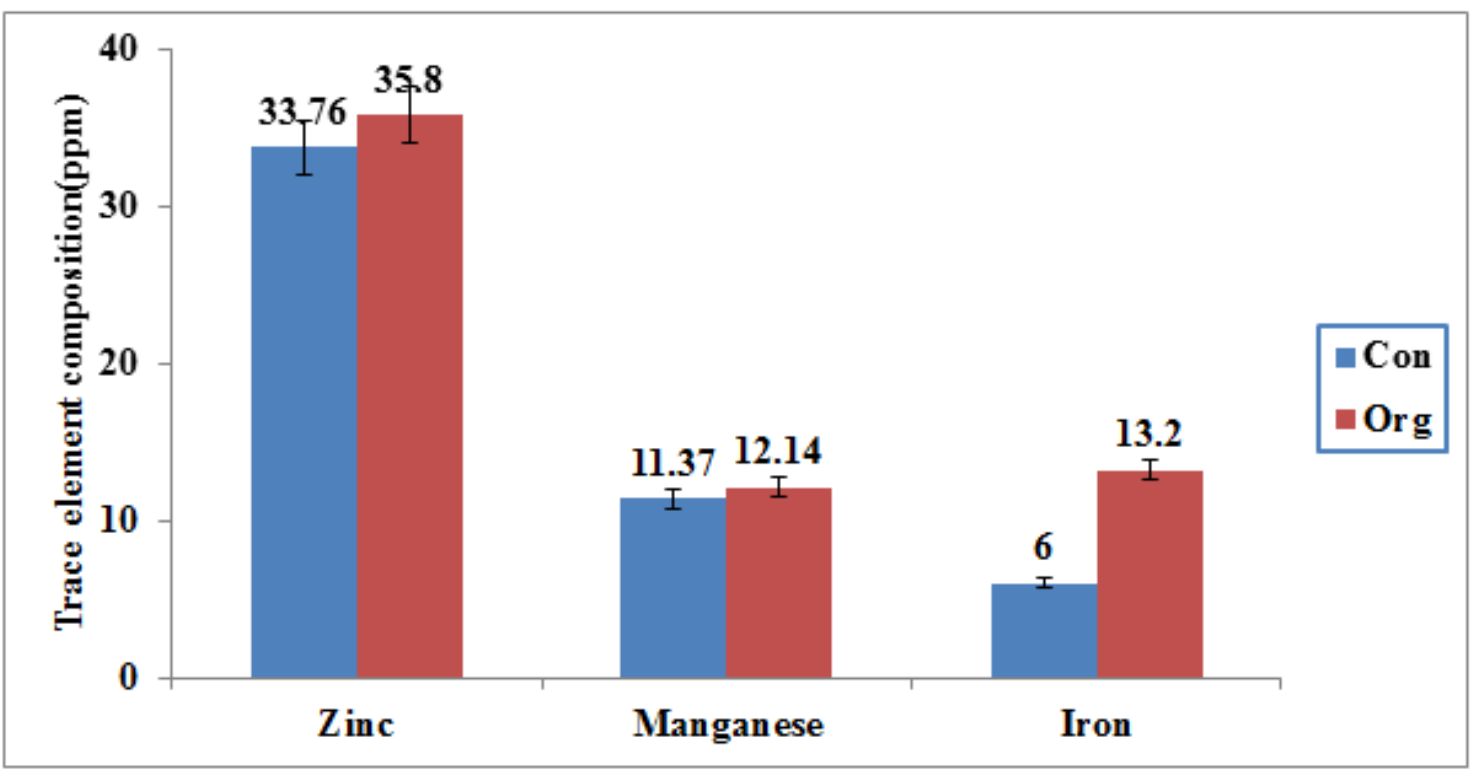

Figure 11. Effect of organic and inorganic nutrient sources on Mineral and trace element composition (ppm) in rice variety Pant Basmati 1 


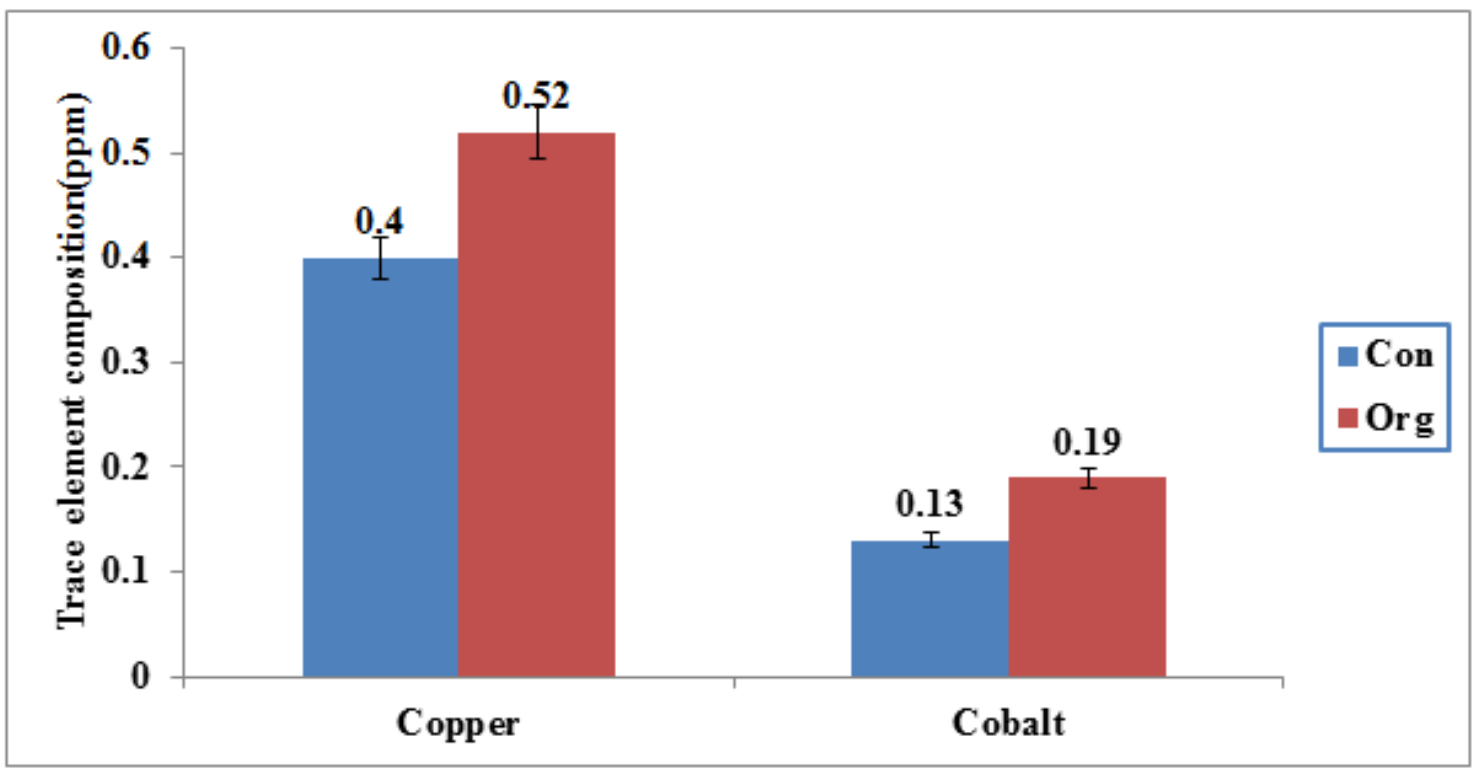

Figure 12. Effect of organic and inorganic nutrient sources on Mineral and trace element composition (ppm) in rice variety Pant Basmati 1

The values for kernel hardness were higher in inorganic samples of rice $(10.52 \mathrm{~kg} /$ grain, ) as compared to that inorganic one $(8.41 \mathrm{~kg} /$ grain $)$ and the difference was found significant in both the cases, which suggests dense packing of biochemical substance in kernels of inorganic crops. Singh et al. (1999) reported grain hardness adversely affects water absorption and delays the cooking process. This was also seen in the present study as hydration capacity of organic samples was more $(0.03 \mathrm{~g}$ for rice, $)$ than that of inorganic ones $(0.02 \mathrm{~g}$ for rice, $)$.

Importance of Rice quality parameters vary between farmers and millers for example farmer give weightage to high yield, minimum moisture content \& minimum spoilage and microbial deterioration whereas for millers, Length, Breadth, translucency, high head rice yield are important.

Length/breadth ratio in organic rice was 3.53 against a value of 2.95 in inorganic rice, which shows that organic rice is finer than inorganic one. In India consumer prefer "fine-grained" rice. The amylose content in organic rice was more (29.48) than that in inorganic rice (23.46). On the basis of classification given by IRRI (1973), organic rice was found to have high amylose content whereas inorganic rice had intermediate amylose content.

Significantly higher values were observed for hulling yield $(\%)$ and milling yield $(\%)$ in inorganic rice as compared to that in organic rice whereas the average value for per cent degree of polishing was slightly more in organic rice as compared to inorganic rice with a non-significant difference between the two (Table 2). The reason for lesser milling yield in organic rice may be that thinner kernels of organic rice with lower grain hardness were more susceptible to breakage during milling. Paul and Siddiq (1986) had mentioned that varieties with high protein content resisted more abrasion as compared to varieties with low protein content [8]. This might be another reason for higher milling yield in inorganic rice (with higher protein content) in comparison to that in organic rice. Organic rice showed higher elongation ratio (1.64) and swelling rate $(0.73)$ as compared to inorganic rice (1.45 and 0.54 , respectively) suggesting a better cooking quality for organic rice, which is a highly desirable trait in good quality rice.

Organic and inorganic boiled rice were subjected to sensory evaluation using sensory scorecard by panel members selected on the basis of triangle test (Table 3). From statistical analysis of data obtained for different parameters, it could be inferred that panel members were not able to find any difference between organic and inorganic samples of boiled rice as both were rated in the same range.

The nutritional quality of the rice was assessed in terms of proximate composition and mineral and trace element composition.

The inorganically grown samples of the rice crops showed significantly higher values for moisture content (14.48\%)as compared to that by organic samples $(11.77 \%)$, thus suggesting more nutrient density in organic rice. Inorganic rice showed significantly higher protein $(7.25 \%)$ as compared to organic rice $(5.57 \%)$. crude fat i.e. in case of rice, inorganic sample showed significantly higher values $(1.02 \%)$ as compared to organic one $(0.86 \%)$ which might be due to different milling proportions. The total ash content was found to be slightly higher in organic samples of rice; however, the difference was not significant. The control decomposition of organic matter, high retention of inorganic nutrients and buffering action of organic matter regulates the release of inorganic constituents in the soil [9]. This might be the reason for higher ash content in the organic sample. No definite trend 
was seen for crude fiber and available carbohydrate. As for crude fiber in case of rice, the inorganic sample showed higher values. Similarly for carbohydrate, organic rice showed higher values in comparison to their counterparts. However, the difference was non-significant. No effect of mode of cultivation on energy value was apparent. The quality of protein was better in organic rice and the value for in-vitro protein digestibility was more $(46.34 \%)$ as compared to that in inorganic samples of rice $(41.95 \%)$. However, statistical analysis revealed that effect of mode of cultivation on in-vitro protein digestibility of rice crops was not significant. The values for all the minerals were higher in organic samples of the rice but a statistically significant difference was seen for iron $(1.32 \mathrm{mg} / 100 \mathrm{~g})$ and phosphorus
$(92.55 \mathrm{mg} / 100 \mathrm{~g})$ in case of organic rice. The significantly higher levels of these minerals in organic crops may be attributed to decreased leaching losses and increased availability of nutrients with the use of organic matter.

\section{Acknowledgment}

The author is highly thankful to GBPUA\&T, for providing the necessary facilities to carry out the research on Comparative Study of Organic \& Conventional System of Crop Production with Reference to Yield Quality, Soil Health \& Biology.

\section{Appendix}

Table 1. Effect of inorganic and organic sources of nutrients on Grain quality in rice variety Pant Basmati 1

\begin{tabular}{|c|c|c|c|c|c|c|c|}
\hline Sample & $\begin{array}{c}\text { Bulk density } \\
(\mathrm{g} / \mathrm{ml})\end{array}$ & $\begin{array}{c}\text { True density } \\
(\mathrm{g} / \mathrm{ml})\end{array}$ & $\begin{array}{c}\text { \#Hardness } \\
(\mathrm{kg} / \mathrm{grain})\end{array}$ & $\begin{array}{c}1000 \text { kernel } \\
\text { weight }(\mathrm{g})\end{array}$ & $\begin{array}{c}\text { Hydration } \\
\text { capacity }(\mathrm{g})\end{array}$ & $\begin{array}{c}\text { Seed volume } \\
(\mathrm{ml})\end{array}$ & $\begin{array}{c}\text { Per cent } \\
\text { porosity }(\%)\end{array}$ \\
\hline Con & 0.74 & 1.57 & 10.54 & 21.50 & 0.02 & 1.05 \\
\hline Org & 0.77 & 1.38 & 8.44 & 22.30 & 0.03 & 1.36 \\
\hline t-value & 0.932 & $8.845^{*}$ & $2.442^{*}$ & -11.381 & -3.360 & -3.162 & $10.875^{*}$ \\
\hline
\end{tabular}

Note: Values are mean of six observations

*Significant difference

\# Values are mean of ten observations

\# tabulated t-value: 2.262 IR-Inorganic rice, OR-Organic rice

Table 2. Effect of inorganic and organic sources of nutrients on Grain quality in rice variety Pant Basmati 1

\begin{tabular}{|c|c|c|c|}
\hline Parameter & Conventional rice & Organic rice \\
\hline Amylose content & 23.46 & 29.46 & 72.40 \\
\hline Hulling yield (\%) & 74.00 & 63.31 & $3.408^{*}$ \\
\hline Milling yield (\%) & 64.04 & 12.68 & $3.165^{*}$ \\
\hline Degree of polishing (\%) & 12.44 & -3.343 \\
\hline \#Length/breadth ratio & 2.95 & -10.384 \\
\hline Alkali score & 4 & -77.459 \\
\hline
\end{tabular}

Note: Values are mean of six observation

stabulated t-value: 2.571

*Significant difference

\# Values are mean of ten observations

\# tabulated t-value: 2.262 IR-Inorganic rice, OR-Organic rice

Table 3. Effect of inorganic and organic sources of nutrients on Grain quality in rice variety Pant Basmati 1

\begin{tabular}{|c|c|c|c|c|c|c|}
\hline Sample & Texture & Color & Taste & Flavor & Appearance & Overall acceptability \\
\hline Con & 7.7 & 7.8 & 7.6 & 7.7 & 7.6 & 7.6 \\
\hline Org & 8.0 & 7.9 & 8.0 & 7.8 & -8.9 & -4.025 \\
\hline t-value & -5.581 & -3.000 & -6.508 & -3.000 & -8 & \\
\hline
\end{tabular}

Note: Values are mean of ten observations

tabulated t-value: 2.262

*Significant difference IR-Inorganic rice, OR-Organic rice 
Table 4. Effect of inorganic and organic sources of nutrients on proximate composition in rice variety Pant Basmati 1

\begin{tabular}{|c|c|c|c|c|c|c|c|}
\hline Sample & Available carbohydrate (\%) & $\begin{array}{c}\text { Moisture } \\
(\%)\end{array}$ & Crude protein (\%) & Crude fat (\%) & Total ash (\%) & Crude fibre (\%) & $\begin{array}{c}\text { Energy } \\
(\mathrm{kcal})\end{array}$ \\
\hline Con & 76.31 & 14.49 & 7.25 & 1.02 & 0.65 & 0.26 & 344 \\
\hline Org & 80.70 & 11.76 & 5.60 & 0.86 & 0.89 & 0.21 & 353 \\
\hline t-value & -17.820 & $39.637^{*}$ & $8.126^{*}$ & $6.708^{*}$ & -10.679 & 2.381 & -19.988 \\
\hline
\end{tabular}

Note: Values are mean of six observations

tabulated t-value: 2.571

*Significant difference

IR-Inorganic rice, OR-Organic rice

Table 5. Effect of inorganic and organic sources of nutrients on Mineral and trace element composition (mg/100 g) in rice variety Pant Basmati 1

\begin{tabular}{|c|c|c|c|c|c|c|c|}
\hline Sample & Iron & Phosphorus & Calcium & Manganese & Cobalt & Zinc & Copper \\
\hline Con & 0.60 & 112.80 & 15.17 & 1.137 & 0.013 & 3.376 & 0.044 \\
\hline Org & 1.32 & 92.55 & 16.70 & 1.214 & 0.019 & 3.580 & 0.052 \\
\hline t-value & $5.084^{*}$ & $7.537^{*}$ & -1.589 & -1.333 & -4.108 & -5.719 & -2.185 \\
\hline
\end{tabular}

Note: Values are mean of six observations

tabulated t-value: 2.5

*Significant difference

IR-Inorganic rice, OR-Organic rice

\section{REFERENCES}

[1] Muthu S. For a bowlful of rice. The Economic Times. 1993.

[2] Vachhani, M. V., Butany, W. T., \& Nair, C. P. K. A tentative commercial classification of rice. Rice Newsletter, 10(15), 1962.

[3] Ramesh P, Singh M and Rao A S. Organic farming: its relevance to the Indian context. Current Sciences 88(4): 561-568, 2005.

[4] Bhattacharya K R, Sowbhagya C M and Indudhara Swami Y M. Some physical properties of paddy and rice and their interrelationship. Journal of Food Science and Agriculture 23: $171,1972$.

[5] Sowbhagya C M and Bhattacharya K R. A simplified colorimetric method for determination of amylose content in rice. Starch 23: 53-56, 1971.

[6] Little R R, Hilder G B and Dawason E H. Differential effect of dilute alkali on 25 varieties of milled white rice. Cereal Chemistry 35: 111-126, 1958.

[7] Wu C, Ye Z, Li H, Wu S, Deng D, Zhu Y, Wong M. Do radial oxygen loss and external aeration affect iron plaque formation and arsenic accumulation and speciation in rice? Journal of experimental botany.15; 63(8):2961-70, 2012.

[8] Paul E and Siddiq E A. Studies on variability for resistance to milling and protein loss on milling and various grain characteristics influencing them in rice (Oryza sativa, L.) Cereal Res. Comm 14: 297-304, 1986.

[9] Chhabra $\mathrm{R}$ and Chhabra A. Concept and feasibility of organic farming in Indian agriculture. Indian Journal of Ecology 30(2): 135-151, 2003. 